This item was submitted to Loughborough's Research Repository by the author.

Items in Figshare are protected by copyright, with all rights reserved, unless otherwise indicated.

\title{
Introduction: transgressions or, beyond the obvious
}

PLEASE CITE THE PUBLISHED VERSION

http://www.palgrave.com/products/title.aspx?PID=259875

\section{PUBLISHER}

(c) Palgrave Macmillan

\section{VERSION}

AM (Accepted Manuscript)

\section{LICENCE}

CC BY-NC-ND 4.0

\section{REPOSITORY RECORD}

Wolfreys, Julian. 2019. "Introduction: Transgressions Or, Beyond the Obvious". figshare. https://hdl.handle.net/2134/8594. 
This item was submitted to Loughborough's Institutional Repository (https://dspace.lboro.ac.uk/) by the author and is made available under the following Creative Commons Licence conditions.

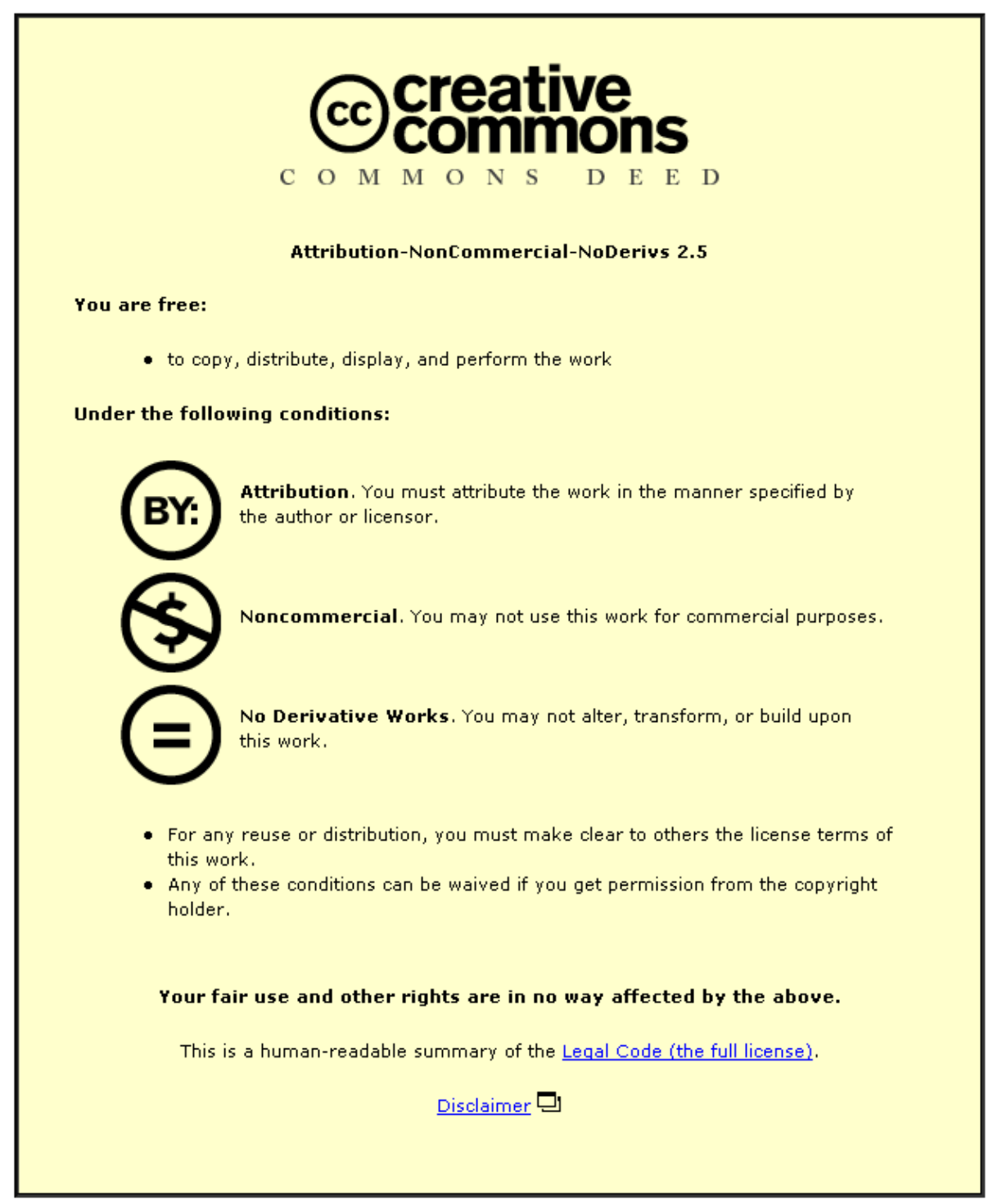

For the full text of this licence, please go to: http://creativecommons.org/licenses/by-nc-nd/2.5/ 
Introduction: Transgressions or, beyond the Obvious

I Recognitions and Misrecognitions

Transgression: it is a common enough word, circulated enough for us all to believe we understand what is meant by it when it is used. Ideas about what constitutes transgression are equally commonplace. Transgression, we might say, goes without saying. Yet, is that in fact the case? Or is it not that we are so used to what we take to be the idea of transgression that we have, in all truth, forgotten, or not even become aware of the extent to which transgression constitutes our identities? Believing we understand the term as indicative of breaking a law, doing something illicit, disrupting order and rebelling against societal norms, if and when we think we transgress we do no more than conform to expectations of acceptable 'deviance'. We act up in a manner already in some sense prescribed, whether socially or historically, and so merely conform in a way that is more or less tolerated, even when excoriated.

Transgression however runs much deeper than that. It is, as I shall argue in the present volume, not merely the breaking of a code, a rebellion against normative social or cultural constraints; rather it is the very pulse that constitutes our identities, and we would have no sense of our own subjectivity were it not for a constant, if discontinuous negotiation with the transgressive otherness by which we are formed and informed. Identity must needs believe in its own stability for the conventions of transgression to apply. However, 'for a subject to imagine itself as having a stable identity', remarks Elisabeth Bronfen, is always an act of misrecognition (mésconnaissance), a fiction, an illusion...'. She continues, 'though language allows for a differentiation between self and Other... this differentiation is never complete and the imaginary register never disappears ... In a sense any image is the death because the negation of 
the thing, for it signifies that something was thought or recognised, not as real but as an image' (Elisabeth Bronfen 1992, 395)

Seeing oneself as having a stable identity is, then, to misrecognize one's selfhood. It is to project an image and take that simulacrum as the reality, as Bronfen suggests. From this basis of misunderstanding or, to anticipate the next citation, from this 'mode of production' that generates the social structure we call the self, the subject or identity, it is an all too easy step to imagine the self negated, the subject beyond the law, situated, and situating itself, in a locus of negativity, opposition, and transgressive rebellion. This leads to the following question. 'If', asks Julia Kristeva, ' in certain modes of production, social structure projects itself...by circumscribing a represented, assumed, encased negativity...how does this closed place function generally, logically, outside the ... system?' (97). Kristeva's inscription of precise location, of an inside and an outside in the definition of proscribed or outlaw act or event is instructive. It comments on the coercive nature of modes of production that are shaped by historical, cultural and ideological forces, which are themselves not stable but which shift endlessly, in order that a 'social structure' such as the subject might be incorporated in the mode of production, (mis)recognised as a product of that mode, or otherwise placed outside, expelled or marginalised. Identifying illicit practice, determined as a negativity in relation to, and yet closed off from the social structure, Kristeva defines in part at least the transgressive subject produced as a historical subject and determined through the reading of a transgressive space or locus. Her description of spatial position, of clearly defined positions based on perceivable oppositions such as I have indicated, is far from uncommon in the thinking of transgressive events.

However, as valuable a starting point as it may be, Kristeva's reading does not take into account sufficiently the endless differentiation implied in Elisabeth Bronfen's argument, and 
so presents through its critique a kind of misunderstanding that is socially pervasive, in as much as Kristeva reinscribes the static structural relations of the binary opposition that informs so much thinking on the transgressive (self/other, inside/outside, and so on). It thus illuminates the fact that we think in somewhat obvious ways about transgression, when we think of it. Keeping it away from ourselves, we speak of the transgressive as beyond the law, beyond the everyday. We site it as a counter-law in its own right. We situate it hygienically and economically, in what we like to think of as an enclosed space. Yet, as I shall argue, such understanding is misunderstanding; and such representation of what we think of as transgression is misrepresentation. Thinking the transgressive in mundane or quotidian ways involves the invocation of a static need to separate, to include and exclude, and so to draw limits or borders. And because we misapprehend in this fashion, transgression can happen again and again, in countless, surprising eruptions from within the very places that we seek to define as safe, controlled and patrolled.

\section{Conventions of Transgression}

Transgression, therefore: the act of breaking a law, committing a crime or sin, doing something illegal, or otherwise acting in some manner proscribed by the various forms or institutions of Law in societies, whether secular or religious, all of which have histories and which themselves are mutable, self-translating. To cross a line, to step across some boundary or move beyond convention-this is what it means, to transgress. To stray from the straight and narrow, to trespass, to overstep a limit-all such definitions share common assumptions, whether explicitly or implicitly. Whether one thinks of breaking civil or moral laws, whether transgression has to do with sexuality or another aspect of accepted behaviour, the common assumptions that 
inform any definition of transgression have to do with (a) form or identity; (b) a movement or motion, a passage of some kind, and therefore implicitly a duration or temporality; and this passage from being on the side of the law to being lawless, for example, hence tres-pass, to pass over or across, to infringe or impose; (c) spatial and relational position or location.

If I pass or cross a line, if I 'depart from the straight and narrow' as the somewhat clichéd, old-fashioned phrase has it, the implication is that while I was in one place, now I am in another. This is the logic implicit in Kristeva's argument. These places are not simply relational; their relation is not neutral. The erstwhile location from which I have departed is, in the context of thinking transgression, always on the side of the law, convention, what is taken socially and culturally, as well as institutionally, to be standard, acceptable, decent, proper, correct, approved or authorized. The present location in which I find myself, in which I have placed myself by my own activity, this is the place of the illicit, the outlaw. This is what transgression means: to step over or beyond a limit or boundary, to cross a threshold, to move beyond the commonly determined bounds (of law, decency, or whatever).

A word more is necessary on the first of the constituent elements of transgression. As we shall have occasion to consider, form and identity are interrelated, particularly in the sense that the form of a literary text serves to inform the reader about a character's identity, while the transgressive actions or attitudes of a character can frequently be worked out not through the character's identity solely but also in the form (or let us call it 'identity') of the literary text in question. For now however, it simply remains to remind ourselves of those three aspects of transgression, to which we will return shortly: identity/form, movement/passage/temporality, and space/location.

What should be clear so far though is that in order for there to be transgression there has to be a law of some sort, there must be axioms by which an institution-society, a 
university, a religious sect or faith-assert, define, and qualifies its identity and limits. These statements of purpose and self-identification are designed in a double fashion. On the one hand, they take on the inevitable quality of self-evident truths, as if the institution in question, rather than constantly defining and redefining its form and identity, were simply making explicit what was already natural, inevitable or common-sensically obvious. The logic of their existence is somewhat circular therefore. On the other hand, such statements, rules, or commandments are produced, amended and supplemented, in order that members or potential members of whatever the institution in question can measure the extent to which they belong, how they might belong, to what extent they are excluded or can never belong.

III Clearing the Ground

This is to speak only of how one becomes defined by others as having acted transgressively. Transgression, conventionally understood, can be taken on also as a deliberate act of defiance, non-acceptance of laws, or rebellion. Transgressive art might be understood as that which sets out consciously to flaunt social and cultural mores, to violate convention, to repulse or to offend. At its most crude, transgressive art and transgression generally are simply those events, practices, or works that set out to shock. To speak critically of transgression is to authorize oneself to address 'ritual, carnival, art, culture and madness' (Jenks 2000, 3). Extending and adding detail to this broad brush depiction, we might acknowledge the following at least: nudity, sex and sexual preferences or gender orientation, so-called sexually deviant acts (watersports, fisting, and so on), swearing; extending our list, we can include slasher movies, snuff movies, horror-porno, punk, Kenneth Tynan saying 'fuck' on the BBC in the mid-1960s, satire, Monty Python's The Life of Brian, blasphemy, tattooing or body-piercing and other 
manifestations of body-art; stepping back before the present day, we can include referring to God in $16^{\text {th }}$ - and $17^{\text {th }}$-century plays, Shakespeare's Titus Andronicus (a play in which, as one student recently described it to me, Shakespeare got 'a bit carried away'), the writings of the Marquis de Sade, Goethe's Elective Affinities, 'posing as a sodomite' in the words of the charges levelled against Oscar Wilde; coming back to the twentieth century, we can point to Dada, Surrealism, transgressive literature such as the work of Kathy Acker or American Psycho by Brett Easton Ellis, Chuck Palahniuk's Fight Club or Crash by J. G. Ballard, the photography of Robert Mapplethorpe, Andres Serrano's Piss Christ...

So far, so obvious, you might say (and so would I). If this were all to transgression-as many take there to be-then I could stop writing here, say no more about the subject, call it a day, and hope that the publisher would print and sell the 2-3 pages I've written up to this point. The End. That would be something, wouldn't it? A book, which from the outside looked relatively normal, having a cover with a title and author, appearing to be of average width (around 160-200 pages, let's say), but which, when you opened it, had nothing on its pages beyond the first 1000 or so words. Had you paid for such a thing you might feel cheated, you might believe that some convention or tacit understanding or agreement between writer, publisher, bookstore and reader had been, well, transgressed. Or you might just think it a cheap trick, worth neither the price of admission nor the paper on which the meagre offering was published. But then again you might think that here was proof that at last you could judge a book by its cover.

And this raises a more serious, if simultaneously, absolutely shallow point: if a book calls itself Transgression or transgressions, do you expect the book to behave in a completely conventional manner? Do you want it to tell you all about transgressions, and all the while present you with an image rather than a reality? Would you want that book to tell you 
authoritatively, and from the side of those modes of production or structuring laws about transgression as though it were outside such acts? Or would you expect it in some manner to engage in transgressions, however minor, performing rather than addressing its topic with a phoney objectivity? Even were you to come to a book on transgression without either set of expectations-which would, in all probability mean that, unthinkingly you were already placed as a subject in a position of thinking that a book of literary criticism should 'simply' describe and define from 'outside' its subject, so to speak-would it not be at least minimally interesting to find yourself in the midst of a project that attempts to clear the ground of the conventional, silently rethinking the transgressive from within, and adopting different positions and different voices, in order, once more, to transgress, however slightly?

This is what I am seeking to do throughout the present volume. It is, in no small measure, why for some readers there might appear to be no real continuity, no real coverage of the subject in any really historical way. What might appear as the jumpiness, the arbitrariness, the picky and patchy idiosyncrasies of this volume is, in fact, a double gesture. On the one hand, without offering either an overarching historical contextualisation, I move from the early modern period to different manifestations and translations of modernity, and from thence to particular critical-theoretical voices. In each example I choose, the production, projection, placement and disruption of subjectivities is a central concern: how are identities formed and how do they come either to be read or to articulate themselves, whether through recognition or misrecognition? And how, moreover do such gestures of self-fashioning (as it is called in the first chapter) involve a necessary transgression, a breaking of boundaries, a stepping across the line? Such questions motivate the various chapters, and where I alight on a form, a critical voice, a single text or a group of texts, I do so because, implicit to my reading is the assumption that the transgressions with which I am concerned figure themselves with an idiocultural- 
historical and material-specificity that is, in the texts in question, particularly acute. On the other hand, I address the different texts I approach in what might, from certain perspectives appear to be a range of 'voices' or 'styles'. I move between different topics and areas of focus and examine those texts from within their structures, through acts of close reading, several of which are 'wire-drawn', as a somewhat obscure, but rather elegant term has it (meaning drawn out to great length, fine spun, elaborately subtle $\left.{ }^{\mathrm{ii}}\right)$, because while transgression surfaces it is recognised only over time, across the space of a text, and within structures and conventions of identity. It might well be asked why this double motion, why the broad historical range without explanation and the overly detailed, fussy frippery of too-close reading; and, furthermore, why the mixture of critical styles, the more or less straightforward literary analysis (as in the example of Spenser), the more or less regular literary-historical methodology of the discussion of the Gothic, and the more or less dialogic model of interpolated dialogues in the final chapter on Giorgio Agamben?

Each of these points warrants a response, and the response returns us to my earlier questions concerning what kind of a book this should be: one that constitutes a constative speech act, that is one which simply talks, as if from the outside or the supposition that there can be an 'outside', of its subject; or one which tries to show, instead of merely telling, one which is a performative act; that is to say a book which is comprised of numerous little acts of transgression, the different style here, the different voice there, the refusal to conform to certain standards, albeit standards, conventions or institutions that are hinted at everywhere. At its simplest, transgression is after all a 'goyyng fro the ryht way', as Lydgate puts it, in the OED's earliest example (from 1426). There is the work of the more or less, that trope insistently reiterated above, and a trope, I have to say, which in its repetition illustrates the extent to which something appears either to take place, almost, or otherwise over-eggs the critical 
pudding. It is a question of seeking repeatedly to go from the right way, departing from convention-and of course, in doing so, affirming that there is no right way, no straightforward approach. My small, mostly technical irritants are intended to overstep the line and limit of what is properly thought a critical overview of a conceptual model, and are effected in order to discomfort or disorientate the reader, to transgress the reader's certainties, his or her knowingness on so common a topic.

Thus regarding the question of the historical, one of my implicit contentions-and doubtless this will be, for some, quite contentious if not, in fact specious-is as follows: whilst it can be argued that all manifestations of transgression are marked by their own singular historicity (the conditions by which the form of transgression is shaped and so gives expression in a singular fashion), it cannot be said that there is any real continuity. If one takes the position-or positions-that I do, that there is no single definable concept of transgression (and this is already implicit in what I have said above about the conventions of reading transgression) because the very idea of transgression being irreducible to conceptualisation inasmuch as it is endlessly self-differentiating and protean, auto-heterogeneous, then there can be no real continuity, and subsequently, no real coverage of the subject in a really historical way. All one would end up doing in trying to produce a single, continuous narrative grounded in history would be to seek out those instances or events of transgression that look like one another, which have a family resemblance in fact.

And so you would end up with a book examining, let's say for argument's sake, sex and sexuality in Shakespeare, sex and sexuality in the eighteenth century, sex and sexuality in the nineteenth-century, and so on. Despite the careful, real scholarship involved in such a worklooking at source documents, dating examples, providing a context of the cultural temperament or temperature of the times-continuity would seek, deliberately or otherwise, to 
erase difference, singularity, divergence, and so erase in part or in toto the very historicity that traces the examples of transgressions, which a real history, whether in terms of old historicism or some newer, quasi- or post-Foucauldian historicism would generate. Indeed, on the back of this I would have to ask what is a 'really historical way'? Is not the very idea-tied so seamlessly to the notion of continuity and the insistence on the 'real', which I have imagined above as the argument of a fictional critic of this project-of a 'really historical way' one which seeks to subordinate its subject to a governable mode of inquiry, as I have just intimated? (It's a little like those critics who insist that while George Eliot is properly historical as a novelist, Charles Dickens, because of his fondness for sentiment and melodrama is not. This fails to appreciate or even begin to read that melodrama, or indeed any other mode of representation, is, to put it simply, just a different code, shot through by the traces of an encrypted historicism.)

My argument, put as baldly as possible, is that transgressions, being many, multiple, and endlessly inventive and self-differentiating, avoid such determinations, such laws of order, logic and narrative. Moreover, they cannot be examined from the outside, for the very reason that they are of the very fabric of the historical, and to isolate them according to a master narrative is to fall foul of critical recuperation into the structural conventions already acknowledged, and with that the belief that the image is the real.

This is why, having spent a large part of the present volume with literary examples, tracing in the process an historical trajectory, more or less, with regard to publication dates (I move from Spenser, through the Restoration and Dryden, onto Gothic novels and the Gothic in the nineteenth century, before moving back and forth in the chapter on Venice between the Romantics and the late twentieth century), I turn to literary criticism and critical theory. The transition is ostensibly abrupt, and so warrants an explanation. 
If you are reading this book, you are in some way or another engaged in the work of criticism, literary or cultural. Reading a book that addresses a concept or quasi-concept such as transgression means that you are interested in the act of reading and the assumptions that inform not only reading but also writing, in an institutional context such as a university, about literature, culture, art, and so on. Reading others' commentaries on literary works involves one in both the practice of criticism and the metacritical discourses that speak about the critical act, how one pursues it, what one's interests are, how one formulates approaches, gives to one's act of reading particular parameters. This is where you start from at least. Turning away from the literary historical focus of the previous four chapters, in the following, and final section, of this book, I turn therefore to two very different critical texts, which come to you in the names of literary critic Harold Bloom and philosopher Giorgio Agamben.

In the chapter on Bloom, I examine one of his most widely read and influential critical works, The Anxiety of Influence. In this chapter, as in that on Agamben, I continue my critical reflection on transgression as this informs one's subjectivity. Sketching a reading of Bloom's theory of the anxiety of influence-the way in which, in order to avoid the undue influence of a poet of an earlier generation the poet of a later generation creatively 'misreads' his predecessor so as to escape such influence-I look at how Bloom's own critical language is one plagued with anxiety. His reading of influence is itself an anxious articulation of a haunted subjectivity, and it is in this critical duplication that I take the signs and traces of transgression to be registered, and where they leave their marks. As with Venice, Gothic, sovereignty, and self-fashioning, identity for the critical voice is always informed, transgressed and translated by, the voices and inscriptions of the other, and one's subjectivity is constituted and reconstituted in a struggle to transgress oneself the limits imposed on one's subjectivity. 
What comes to one may deform as much as it informs, but such destabilization need not be the cause of fear, anxiety, or abjection. Most neutrally perhaps, one's transgression by the other is an experience of ex-stasis. Not simply, or, more accurately, not yet ecstasy-for to choose this word would imply an aesthetic or phenomenal value, great joy or frenzy which one has already passed through and on which one has reflected, named and given a determination to-what I am calling ex-stasis is just the apperception of being moved out of (ex) that illusory, often non-reflective sense of equilibrium (stasis) which one associates with one's 'normal' subjective state. In many cases, being moved by another out of oneself, finding oneself psychically and emotionally traversed by another, by the trace of another, is to find oneself in love and transgressed by love. Love is thus the final name for transgression in this volume, and I illustrate and explore its workings not through a romance, a novel or other convenient fiction but instead in the philosophical and literary-critical essays of Italian philosopher Giorgio Agamben. Agamben's texts are frequently 'interrupted' by the signs of love; and thus his publications offer us an analogical model for thinking about love's transgression, the way in which that which is other to system, order or coherent programme, nevertheless takes one by surprise, crossing the threshold of one's identity and, in this motion of transgression, translating or transforming the subject, revealing to that subject, the other within oneself, one's very own endlessly transgressive force or play.

Like anxiety, love is thus seen as a phantasmic or spectral transgression. Yet, I would argue, what transgression is not this, if we are to reflect on transgressions beyond the obvious and everyday physical or material instances of the commonly understood transgressive, which beyond it is the purpose of this book to pursue? Perhaps not a little idiosyncratically, I have specifically chosen to very singular critical texts as the subjects with which to conclude the present volume, precisely because, on the one hand, every act of reading constitutes a 
transgression; it crosses the line, you cross the line, the limit, boundary or threshold of a text every time you open it, enter it. Conversely, every text enters you, causes you to reflect, to think. On the other hand, my concluding subjects have been chosen because, despite their very different focus (criticism rather than literature), what they share, however idiomatically, not only with one another but also with each of the literary texts I have explored here, is the focus on the realm and work of the imaginary in the material formation of subjectivity, and the essentially phantasmic role of transgressions in the cultural histories of human identity, in all its fluidity. Bloom and Agamben are here simply because, at the same time as they offer examples in different discourses of the manner in which subjectivity is fundamentally 'haunted' (the implicit argument behind the chapters on Gothic and Venice), they foreground, deliberately or not, intentionally or otherwise, the extent to which being human means not only to be transgressed but also to be transgressive. Subjectivity is always grounded, historically, culturally, ideologically, epistemologically, in space and time; being is always a being-in-theworld, a being-there as Martin Heidegger would have it. But equally, subjectivity is never fixed, it is semi-porous, mutable, ineluctably protean, fluctuating, and discontinuously differentiated within itselves and its others. Before sin, disobedience, misbehaviour or wrongdoing, transgression is always the limitless capacity of the subject to break its own limits and still remain itself.

\section{Shifting Positions}

This might have begun to seem like mere metacritical filigree work. There is a point to this though, as the number of subject positions-subject positions by the way that I 'imagine' or 'invent' in each of the chapters that follows through the staging of their different voices-I have 
imagined in the previous section should imply. What is transgressive for one person is not for another. Concomitantly, and if you look back over my taxonomy of transgressive examples, what is transgressive in one age is not in another. Neither is the transgressive easily or simply defined as that which any normative or hegemonic group in a society or institution decide on, especially if the artist or writer or another group without power or on the margins of society argue that they are not being transgressive. For example, there have been long stretches throughout history when same-sex relationships were regarded as unnatural, perverse, deviant, against the laws of man (sic) and God; indeed, there still remain large groups of bigots today whose homophobia and, often, religious faith, allows them to see homosexuality as transgressive. To turn to literature and art, perhaps Brett Easton Ellis wished to be transgressive when he wrote American Psycho. I do not know. But if I did not find it so when I read it, and instead merely found it boring, banal, predictable, mundane, obvious, then was it transgressive? Equally, Andres Serrano may not have sought to be transgressive, but numbers of Christians (not all, it is important to remark) found Piss Christ deeply offensive (even the title of the work today will give pause to some, as you read it here). It is important to acknowledge then once more that there is no transgression, if by this term one means a stable or constant, universal concept, which is transferable from situation to situation, event to occasion, from era to era, constituency to constituency. Transgressions, plural, take place but because what is transgression for one is affirmation for another, what is the disruption of form or institution for some is the assertion of identity for others, the very notion of transgression can never be defined as more than an abstract notion understood as the traversal of a boundary, and with that motion or passage the deformation of the limits of form, identity or institution momentarily or provisionally. In this, we find ourselves back at that line of Lydgate's from the fifteenth century. 
V Transgressions: Subject, Space and Time

If there are constants, or quasi-constants, these emerge in the present volume as those focal points relating the subject's identity to matters of temporality and space. The 'place' where the three come together is memory. Memory serves as the figure for speaking of the relation between the three 'topics' or topoi of this volume-identity, space, and time-as they come to touch on one another in our thinking of the constitution and dissolution of the transgressive movement or passage. In the sense that transgression is always a motion that disturbs borders and the understanding of what is included and excluded by any boundary, that it can be argued that memory is transgressive. Why? Well, as a starting point in reorientating ourselves to this suggestion, memory, it has to be admitted, can arrive at any time. Equally, unbidden, it slips away. In either case, memory is always the movement or passage across a certain limit, boundary or margin.

Like the trace of a phantom, it comes to pass, unbidden, at different times, and with different speeds. Memory does not wait for my consciousness to call it up, but can appear, in any moment, returning across the threshold. It moves across several thresholds and 'places'; between for example, the unconscious and the conscious mind, between remembering and forgetting, and, more subtly, and to give this a temporal dimension that the structural examples just alluded to do not acknowledge, memory moves as a recording of the past from the moment of its transcription to the moment of its reiteration. In this passage, it crosses the boundary not between a past and a present, that is to say the past of an experience or event recorded by the mind or the present of that mind's recollection of the event or experience 
through the inscribed or recorded trace of the thing itself. Memory thus transgresses a border between what is real and what is phantasmatic, between a materiality and the registration of that material condition or set of conditions. In this, it bears a relationship with the experience of the uncanny, which is to be explored in the third chapter. However, to remain with memory's passage, in this motion, memory is transgressive in another fashion, for in its 'travel' it undoes any neat distinction between truth and falsity. In being a memory it necessarily makes of material and historical experience a narrative, and to the extent that all narrative is an ordered account that privileges certain events over others, leaving particular details out whilst giving added emphasis to others, narrative, like memory 'fictionalizes'; it tells a tale in a manner that is neither simply true nor false. Indeed, the very categories themselves of truth or falsity, real or imagined, are shown to be marked by limits that memory can and does overstep.

Now, my example of memory as transgressive immediately problematizes the conventional or journalistic wisdom on what constitutes transgression, which relies on a conscious or deliberate act. According to the understanding of the way memory can and does work on many occasions, it comes and goes without conscious volition. I can be thinking or doing one thing (writing this book, reading another, walking, running, watching a movie, travelling around a city where I don't live) but what I think of as 'my' memory will disturb mepleasantly or otherwise-by bringing to mind an experience to which I am giving no conscious consideration. It therefore arrives as some other, which is simultaneously both of me and not me. It figures as the trace of another me, of myself as an other. A trace of this other self therefore comes to pass for me, as a result, possibly, of some obscure or occluded association made in the most indirect manner. Phantasmically, the from over the threshold of consciousness the fragment of another's life arrives to disrupt for a moment the borders of my identity, my identity as I apprehend it in a given now. That present identity can reassert itself, 
the memory having retreated, the instant of transgression being brief. Thus it is we find ourselves with those three elements of transition I identified earlier and their non-synonymous substitutions, identity (form), passage (movement), and location (space or spacing).

\section{Rethinking Transgressions}

At the risk of repeating myself, beyond whatever is framed or positioned in this introduction, I am not be proposing a theory of transgression any more than I am seeking to construct a history of the same. To do so would strive, once more, to institutionalize and make normal the very idea. Where I do have recourse to particular theoretical texts, this is so as to illuminate and offer a more rigorous reflection on transgression. What follows therefore is a consideration of particular reflections on and mediations of the notion of transgression, in order that we can, in moving through a few of the necessary founding arguments, open the subject beyond itself, and so step beyond the path critical interventions have taken.

The transgressive text is not the one that shocks. Not necessarily. It is not a play, film, novel, work of art or fiction that represents violent or excessive acts. Nothing is more banal, mundane, predictable, and quotidian. Of course, a text may portray such events, or it may narrate sexual encounters of various kinds, either in a manner that disturbs or of a kind, which for a particular audience are upsetting, outrageous, gratuitous. And yet, these are not necessarily transgressive in themselves. What I have in mind in speaking of the transgressive text is that form which, playing on all the codes conventionally belonging to what Roland Barthes calls the 'structure or grammar of Narrative' (1994, 261), effects departures from the conventions, and which, additionally, displaces narrative significance to a marginal place, locating it as a secondary concern, whilst foregrounding process, space, 'other texts, other 
codes...articulated...in terms of society, of History....according to citational' rather than 'determinist paths' (Barthes 1994, 261). Borrowing from Barthes' definition of textual analysis, I am attempting to present a notion of textual explication, which, whilst grounded in close reading, nonetheless resists apprehending textual form as a discrete, contained whole on the understanding that a text is already transgressive. It is not defined by the narrative it presents, even though narrative is a significant component. Every text is therefore a transgressive text; or any text can be read as transgressive in principle. To put this another way, within and other than the semantic trajectory or horizon, the 'unified' content of a particular textual form, there is to be another text which gives access to, and inaugurates various transgressive departures borne out of the singular structural manifestation of an otherwise 'combinative infinity' (Barthes 1994, 265).

This is the first aspect of reading transgression. It involves a reorientation of the act of reading, so that reading, responding to those codes or traces that gesture beyond narrative or representational coherence and exceed the limits of the form, becomes, itself transgressive. More specifically, the transgressive reading is one that recognises those traces in any text which are themselves disruptive of conventional and institutional codes. As Barthes puts it, 'to transgress is both to recognize and to reverse; the object ... must be presented and denied at the same time' (1967, 47; emphasis added). The emphasis on recognition points to what is embedded within the text, reversal stressing the reader's active work in the production of the text, thereby transgressing the limits of reading after coherence. At the heart of the transgressive pulse, there are the signs of practices in writing and other aesthetic phenomena encrypted 'inversions or negations of cultural rules', as Susan Stewart has argued $(1991,3)$. The teaching of reading has sought to regulate or negate those negations. It has attempted to muffle the dissonant oscillations within any textual network. The question of reading transgression 
involves therefore engaging in a contest over the materiality of the signification and the rights of exegesis pertaining thereto. As Susan Stewart has observed of literary production, the law 'exists in a distant space'; she continues, [it] is already written, and has written the present' (1991, 21). Despite this, the text exceeds the law that determines its form. It does so not in any simple dialectical contest. Instead, with an irony that is sometimes po-faced, sometimes hilariously parodic, it imitates the law in what amounts, each time, to a singular explication $d u$ texte, and in so doing crosses the line the law has drawn in order to give to the text a governed identity. This has always been the case, as Michel Foucault has had occasion to observe in a different context, on the history of authorship: 'it was at the moment when a system of ownership and strict copyright rules were established ... that the transgressive properties always intrinsic to the act of writing become the forceful imperative of literature' (1979, 124-25).

Now, while in citing Foucault, I have shifted from reflections on what takes place intrinsically in writing to the 'external' and material conditions of authorship and the role of writing as a system of production within a legal system, one cannot separate the internal from the external, particularly apropos the subject of the literary text. There is to be observed between Stewart or Barthes' comments and those of Foucault a motion or passage from 'inside' to 'outside', as it were. Transgression and authority are intimately entwined then at different levels, from discourse to practice, one making the conditions for the generation of the other. To take but one example of literary production that bears out the more general assertion, the novel, Tony Tanner has commented in his study of adultery in the novel that, '[t]he novel, in its origin, might almost be said to be a transgressive mode, inasmuch as it seemed to break, or mix, or adulterate the existing genre-expectations of the time' (Tanner 1979, 3). The reciprocal relation is less one of antagonism than of mutual dependency, for, historically speaking, no system or institution can survive without adaptation. The institutions of literature and 
authorship constrain and contain textual production, and the subject matter of production exceeds what is authorised. In order to maintain themselves, the institutions adapt, taking in just enough of what is transgressive to preserve themselves, needing the very transgressions-or some-which they proscribe. Thus, transgression becomes the norm, making way in having been accommodated, for other transgressions. This potentially endless process is further complicated because in the modern era literature has the right to say whatever it wishes in its own ways, without censorship or interdiction. The very system of literature is predicated then on its being an open and auto-transgressive system, a mutable or protean identity that is always already hetero-normative. In being transgressive, the literary is a parasitical organism, an exogenous entity transgressing the boundaries of countless discourses and systems, and cannibalizing their resources.

'Transgression', writes Chris Jenks in his study of the subject, in which he addresses, amongst others, Bataille, the Marquis de Sade, Freud and the concept of taboo, Nietzsche and morality, Artaud, Rimbaud, Bakhtin, Dada and Surrealism, 'is that which exceeds boundaries or exceeds limits' $(2000,7)$. This echoes what we have already affirmed, earlier in this introduction. However, he cautions, 'we need to affirm that human experience is the constant experience of limits, perhaps because of the absolute finitude of death... Constraint is a constant experience in our action, it needs to be to render us social' (7). As he continues, constraint is never imposed solely from outside ourselves. Rather we limit ourselves regarding our behaviour. Or at least we believe we do. For it is the case that the ways in which we regulate our actions, believing that we act on the limits within which we live (or not), are not natural. There is not some 'Law of Nature' that we transgress as John Locke believed, which Law is translated into institutional secular and religious forms by those who rule us. Regulations and the systems to which they belong are cultural and historical manifestations which we learn, and 
which we impose, for the most part, to greater or lesser degrees, on ourselves. Each of us is produced as our own policeman-or policewoman. Literary texts repeatedly mediate this duality, the outside system become internal measure or, as Jenks has it '[t]ransgression is part of the social process, [but] it is part of the individual psyche' $(2000,186)$.

Thus, the novel, plays or films seek to work through the paradox that one transgresses because one's survival is threatened by what, to many, is convention or normative behaviour. Without the transgression deemed to be out of bounds or beyond the pale (to recall the spatial motion and the topography inhabited by the transgressing self), the self will disappear. Art in its many guises invites the reader, occupying a safe space (a gallery, a theatre, the rooms at home in which one reads), to look at 'the precarious edges of experience, where oppressions meanings are negotiated and sometimes reconstructed' (Palmer 2000, 453), whether those oppressions are, generally, the past (tradition, heritage, history) as inherited weight the stifles subjectivity and authenticity, the institutions of the present, or the limits to experience I negotiate as 'my own'. One manifestation of transgression in nineteenth-century literature, lying, offers a form of preservation of the otherwise 'honest' self, until the subject who lies is reconciled with, the society, by which he or she has become marginalized as John Kucich has demonstrated extensively (1994).

Literature and other forms of aesthetic text might then be understood as transgressively affirmative or, otherwise, as so many 'aporias of resistance' (to borrow Elisabeth Bronfen's fine phrase; 1992, 395), and in the following double manner. Internally, narratives in which transgression takes place beyond the obvious criminality and illicit trajectory, foreground the limits of social logic by unveiling the mechanisms of survival by which characters, normally 'moral', are forced to survive by becoming 'outlaws' because of social inflexibility. The paradox within social systems that produces the strategic illicit action opens the potential for reform 
and transformation. Externally, there is the relation between the text and its reader, or audience. Whilst I police myself, my minor transgressions and excesses all too common, too quotidian, imaginary spaces, those forms of phantasmic embodiment we call textual or literary, allow me another kind of transgression. I can get 'outside' myself, as it were. I can exceed my being and my world, crossing over the boundary from reality to the invented world, and experience by proxy the events of another. These events or experiences need not be of the 'obvious' variety. It is not a question of anything as trivial or banal as reading about serial killers, monsters, drug addicts, and so on. The transgression is in the imagined step beyond the self into any other life, losing the self in other possibilities. Such action may well be purely pleasurable, but often the texts in question are written from a need to explore, and at the same time to remain within the law. As we shall see, literature opens one to the encounter with countless others, but gives transgressive access beyond repetition of the law to inventions of the national self, to translations of the subject through displacement and disorientation as a result of physical and geographical location, and to experiences involving an interrogation of the very means by which one's identity is placed within cultures, societies and traditions.

In conclusion, then, transgression does not break absolutely with this placement. Rather it indicates a moment of becoming, an event erupting from out of a multiplicity of possibilities in the textual and cultural formation of knowledge where transition is irreversible. Transgression takes place, where it takes place, as a 'foundational interruption' (Badiou 2005, 81). Understanding this, by the way, and taking on board the full measure of its implications, I end with an examination of ghostly inheritance. To put this another way, the volume concludes with particular transgressions of the self, given the names of 'anxiety', an anxiety concerning the influence of the past-and therefore staged through the imagined subject finding him- or herself transgressed temporally-on any present moment of articulation; and 
'love', this singular example of transgression being understood spatially, as that which arrives from some other place and some other subject. These are expressed most succinctly in the work of Harold Bloom and in the philosophy and literary criticism of Giorgio Agamben. Both critics' work, though often incommensurably different, is nonetheless structured around a response to reading foundational interruptions in the constitution of the subject. One breaks a contract which then, in response, reforms, to maintain the production of historical knowledge, consciousness, and meaning in discourse. The transgressive as movement sends out for reading a proposition submitted, as Jacques Derrida would have it of the Hegelian text, 'an interpretive decision' as the imperative of all 'logical continuity' (1978, 260). In this move, Derrida inaugurates a reading of the transgressive in Bataille qua negativity and affirmation simultaneously. (Which of course is an a mode of 'originary transgression', if you will, for at the very heart of transgression is the transgression of ontology or meaning that makes possible the impossible simultaneity just signalled.) Discourse is thus opened within itself to a loss. It finds itself opened by a negativity within its own conditions of representation-and in this we come to read the foundational interruption and the affirmative event. Put another way discourse transgresses itself-but only, as Derrida insists, on the very condition that 'this transgression of discourse', and as he remarks parenthetically, 'consequently of law in general', must 'in some fashion...conserve or confirm that which hit exceeds. This is the only way for it to affirm itself as transgression and thereby to acceed' $(1978,274)$ to whichever law, whichever order or continuum, whichever historical, material or metaphysical 'truth' is presented through the violence of the provisional rupture and passage. When cultural 'truth' or meaning is made nonsensical through a revelation concerning the logical limits of any law or system of representation then 'the world of meaning' is linked to 'the world of nonmeaning' $(1978,275)$ and violence, destruction, negative force ensue so as to claim a becoming of identity and being 
that gestures towards the future through its 'transgressive affirmation' $(1978,274)$. Such transgressive affirmation and, reciprocally, any affirmative transgression is, we may reflect as we bring this introduction to a close, to be encountered in the reader's experience of the image and text. Texts are discursively promiscuous, often despite themselves or their authors. In the image, the trope, and other figures of the text irreducible to semantic stability, meaning is not upheld. Rather there occurs an 'affective resonance' (Cable 1995, 9) as unlooked-for authoring of the self emerging from an encounter, an intersection-here, in short, the motive, motif, and motivation beyond the conventional, the commonplace, the obvious, all those mystified dimensions of our social selves by which we are surrounded. 


\section{Notes}

${ }^{\mathrm{i}}$ The line before this footnote is, more or less, a citation. It is not in quotation marks and there is no page number, because it comes, more or less, from an anonymous commentary on the present project at a draft stage. I cite it for the purpose of illuminating my argument concerning the reading of transgression, rather than because I think the impulse behind it necessarily inaccurate. A number of that reader's comments are urgently pertinent to the thinking of a project such as this, and revisions, emendations, and new passages have been included, both in this introduction and elsewhere throughout the book as a result, for which impetus I thank the anonymous reader.

ii The reader mentioned above uses the term 'wire-drawn' in her evaluation, and again I thank her for introducing this word to me. The definition I have given is the earliest, taken from the OED, which cites. Whilst writers as different as Ben Jonson, Thomas Carlyle, and Thomas Hardy use the word if not wholly positively, then certainly with an ironic ambiguity, the reader seems to use it more as a nonce-word meaning 'thin' and 'weak'. I also draw the phrase 'more or less' from the reader's comments. 